sion. Furthermore, before the Wendy Savage case a doctor was never able to vindicate himself or herself publicly because hearings under the HM (61)112 procedure were held in secret. Fortunately, the High Court decreed that "the maxim that 'justice must not only be done but must manifestly be seen to be done' applies in full measure" to the 190 procedure (judgment of 21 July 1986$){ }^{1}$

Derby DE3 7BW

EDWina Darnell

1 The Queen $v$ the Secretary of State ex parte Dr Royce Darnell. High Courts of Justice, Queens Bench Division, London. High Courts of Justice, Queens
Judgment given 21 July 1987.

2 Dyer C. A "sad and disturbing" case of dismissal of a consultant: DHSS overruled. Br Med f 1986;293:322-3.

3 Savage W. A savage enquiny: who controls childbirth. London: Virago, 1986.

\section{Aftermath of Chernobyl}

SIR,-In your Medical News (28 March, p 843) you state incorrectly that "the predicted number of extra cancers due to the Chernobyl accident is about 1000." The National Radiological Protection Board's (NRPB) report makes it clear that this is the number of extra fatal cancers predicted for the European Community."

The report quotes a figure of 2000 for the number of thyroid cancers, and states as an assumption that $5 \%$ of these would be fatal. No figure is given for the number of non-fatal cancers likely to be caused by radionuclides other than iodine-131. The number of non-fatal cancers due to these radionuclides (principally caesium-137 and caesium-134) may be obtained from the board's dose estimates by assuming that the number of extra non-fatal cancers is likely to be roughly equal to the number of fatal cancers. This is the assumption made in the United Nations report, ${ }^{2}$ which is the source of the NRPB's cancer risk estimates. This would imply another 1000 non-fatal cancers.

Thus the predicted number of extra cancers in the European Community, based on the board's assumptions, should be 4000 (2000 mostly nonfatal thyroid cancers from iodine-131 and 1000 fatal cancers and 1000 non-fatal cancers from other radionuclides). This calculation leaves out of account the fact that the cancer risk estimates used in the NRPB paper are a matter of dispute. For example, Radford, who chaired the committee on the biological effects of ionising radiation, argued for a cancer risk estimate four times higher than that used in the NRPB paper. ${ }^{3}$

We should, of course, remember that the NRPB paper refers only to the part of Europe in which the accident did not take place.

London SE13 7PL

MARTIN DACE

1 Morrey M, Brown J, Williams JA, et al. A preliminary assessmen of the radiological impact of the Chernobyl reactor accident on the population of the European Community. Harwell: National population of the European Community.

2 United Nations Scientific Committee on the Effects of Atomic Radiation (UNSCEAR). Sources and effects of ionising radiation. New York: United Nations, 1977:6.

3 Radford EP. In: Committee on the biological effects of ionising radiations. The effects on populations of exposure to low levels of ionising radiation. Washington: National Academy Press, 1980:249.

\section{Retiring}

SIR,-Dr Andrew Smith's Personal View (28 March, p 834) was a sad story told by a general practitioner who found himself unprepared for this event.

I retired last year and did not gradually cut down. I remember, shortly after my 65 th birthday, looking after 5400 patients alone when my partner and the trainee were on holiday. It was exhilarating, and I still worked as if trying to create a reputation. But when I did retire my mind was prepared. A chapter of my life was finished. Five days after the lovely party given for me by colleagues we went off to Spain. When we returned two months later I felt little or no curiosity about the practice because I no longer belonged. I disappeared off the face of South Norwood, and I have never had the faintest wish to return to practice. I gave my all to my patients for 31 years, and would now hate to do a locum. A doctor who feels grateful for the crumbs of locum work is feeding through an occluding umbilical cord.

I found that I had been culturally and intellectually starved, even by so broad a subject as medicine. I was ignorant of any literature other than medical literature. Now I enjoy reading Blasco Ibañez in Spanish, and I am trying this year to read as much Russian literature as I can. There is in fact too little time for all I want to do, and I truly wonder how I ever bore with the hours listening to the unhappiness of my patients. I would advise doctors to put everything into their practice certainly; but never let medicine dominate to the extent that you cannot leave it alone. Do not make the gratitude of your patients a source of too much satisfaction, nor imagine you are deeply loved by your patients.

I hope Dr Smith's frank Personal View will not deter others from retiring. My only complaint is that 65 is rather late. Would that I could have afforded it five or ten years earlier.

\section{KeITH ThOMPSON}

Croydon CR0 5NS

\section{Chlormethiazole and alcohol: a lethal cocktail}

SIR,-Dr Gordon T McInnes provides a timely warning about the dangers of using chlormethiazole to treat the alcohol withdrawal syndrome especially in outpatients; but he does not discus the use of drugs other than the sedative-hypnotic group in this context (7 March, p 592).

Carbamazepine has been found to be effective in treating alcohol withdrawal, including delirium tremens, and compares well with chlormethiazole in double blind comparisons. ${ }^{12}$ Although sometimes combined with small doses of benzodiazepines, carbamazepine is effective without adjunctive medication ${ }^{3}$ and offers the advantage of a rapid return to work ${ }^{4}$ or early induction into an alcoholism treatment programme. Its major advantages over chlormethiazole and the benzodiazepines are that it induces neither tolerance nor dependence and suffers no toxic interaction with alcohol.

Clonidine has also been used with some success to treat alcohol withdrawal. ${ }^{5}$ Like carbamazepine, it carries the advantages of shortening hospital stay, lack of toxicity in combination with alcohol, and absence of liability to dependence or misuse ("rebound" hypertension does not appear to be a problem in short term use ${ }^{6}$ ). When there is a history of seizures it may be wise to use adjunctive prophylactic anticonvulsants until clonidine is more fully evaluated. Lofexidine, a clonidine analogue with less hypnotic effect, has also been used with some benefit. ${ }^{6}$

Neither carbamazepine nor clonidine holds a product licence in Britain for use in managing alcohol withdrawal. But there are enough published reports in support of the use of carbamazepine for this purpose, and it has advantages over more traditionally used drugs. Further research is called for in developing these (or other) treatments of the alcohol withdrawal syndrome in an effort to avoid the dangers associated with traditional regimens.

Christopher COOK MAURICE LIPSEDGE

Guy's Hospital,

London SE1

1 Ballenger JC, Post RM. Carbamazepine in alcohol withdrawal syndromes and schizophrenia psychoses. Psychopharmacol Bull 1984;20:572-84.

2 Ritola E, Malinen L. A double blind comparison of carbamazepine and chlormethiazole in the treatment of alcoho withdrawal syndrome. Acta Psychiatr Scand 1981;64:254-9.

3 Agricola $R$, Mazarino $M$, Urani $R$. Treatment of acute alcohol withdrawal syndrome with carbamazepine: a double blind comparison with tiapride. I Int Med Res 1982;10:160-5.

4 Bond WW. Psychiatric indications for clonidine: the neuropharmacologic and clinical basis. I Clin Psychopharmacol 1986;6:81-7.

5 Gold MS, Redmond DE, Kleber. HD. Clonidine blocks acute opiate withdrawal symptoms. Lancet 1978;ii:599-602.

6 Brunning J, Mumford JP, Keaney FP. Lofexidine in alcohol withdrawal states. Alcohol and Alcoholism 1986;21:167-70.

\section{Failure to observe statistical guidelines}

SIR,-In the past few years articles have appeared in the $B M \mathcal{F}$ giving statistical guidelines for contributors to medical journals ${ }^{1}$ and in particular encouraging the use of confidence intervals. ${ }^{2}$ Consequently one would hope that the quality of statistical content in published articles would improve. Unfortunately in a recent edition (28 February) three articles appear which include inappropriate statistical methods.

All three articles (pp 531, 534, 540) include examples of paired data: a crossover trial of placebo versus slow sodium, comparison of alcoholic brains matched with controls, and measurement of urinary frequency before and after treatment. The correct analysis of this type of data should be based on paired differences. It is not always clear from their reports what these authors have done, but in the presentation of these data the pairing is ignored. The data are presented with standard errors or standard deviations for each group separately, whereas a more appropriate statistic to show is the confidence interval for the change in the measurement.

On the basis of this particular edition it appears that the statistical guidelines are not being followed by some authors and, perhaps more importantly, are not being enforced by referees.

Cecilia C A Macintyre GILLIAN M RAAB

Medical Statistics Unit,

Medical Statistic

Medical School,

1 Altman DG, Gore SM, Gardner MJ, Pocock SJ. Statistical guidelines for contributors to medical journals. $\mathrm{Br}$ Med $\mathrm{J}$ 1983;286:1489-93.

2 Gardner MJ, Altman DG. Confidence intervals rather than $P$ values: estimation rather than hypothesis testing. $\mathrm{Br}$ Med $\mathcal{F}$ 1986;292:746-50.

Congenital rubella in babies of south Asian women in England and Wales

SIR,-Dr Elizabeth Miller and coworkers (21 March, p 737) suggests that ethnic minority groups less well defined than Asian immigrants may also be at increased risk of congenital rubella. Our findings support this suggestion.

Antenatal rubella serology by single radial haemolysis of patients attending our practice for maternity services from March 1986 to February 1987 was reviewed. The two largest ethnic groups were white women of United Kingdom origin and Malaysians (postgraduate students or their spouses). Of the 19 white women, one was re- 
ported to have an equivocal rubella state (single radial haemolysis $6.6 \mathrm{~mm}$ ); the 18 others were immune. Of the 16 Malaysians, six were reported to be susceptible, and five of these had no detectable antibody to rubella. The groups were similar in terms of parity, though the mean age of the Malaysian group was higher $(25.2$ years $v$ 22.4 years). The mean single radial haemolysis of the white group was $10.3(\mathrm{SD} 1.51) \mathrm{mm}$ and that of the Malaysian group $6 \cdot 2(4 \cdot 60) \mathrm{mm}(p=0 \cdot 001)$. These findings suggest that Malaysians living in the United Kingdom may be another group at increased risk of congenital rubella. Malaysia is known not to have an immunisation policy for rubella.

In the absence of a vaccination programme aimed at national elimination of rubella in the United Kingdom, it may be possible to include appropriate advice to immigrants at entry to Britain. Immigrants and foreign students may not register with a general practitioner until they require medical attention, and thus at present there is often no opportunity to check rubella state before pregnancy.

Christine M Crawford

Glasgow G3 7HQ

\section{Guidelines on halothane}

SIR,-We are concerned that the closing paragraph of the recent letter by Professor Michael Rosen (28 March, p 836) may lead to misunderstanding about the recent guidelines of the Committee on Safety of Medicines on the use of halothane, as published in Current Problems No 18 (September 1986). The Current Problems article advised that a number of precautions should be taken regarding the use of halothane. Firstly, a careful anaesthetic history should be taken to determine previous exposure and previous reactions to halothane. Secondly, repeated exposure to halothane within three months 'should be avoided unless there are overriding clinical circumstances. Thirdly, a history of unexplained jaundice or fever in a patient after exposure to halothane is an absolute contraindication to its future use in that patient.

These precautions considerably strengthen those previously given by the committee on the use of halothane.

Abraham Goldberg

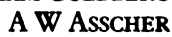

Committee on Safety of Medicines, London SW8 5NQ

\section{Campaign on hours of work}

SIR,-I was surprised that paediatrics, and specifically neonatal intensive care, were not mentioned in the BMA's press release on out of hours work (21 March, p 785) and would like to redress this imbalance.

Consultant paediatricians have one of the highest call out rates of any specialty, and it is inconceivable that their junior staff have an easy time on call, as is suggested by their omission from the list. Data from the Office of Manpower Economics published in the Hospital Junior Staff Committee's annual report show that paediatricians have among the highest weekly hours contracted and among the highest average weekly hours worked when all acute specialties are considered. In view of the heavy workload, in a specialty where cold admissions are the exception, most registrars are resident on call, in contrast to similar grades in many other specialties. Because first on call is staffed by postregistration senior house officers the facility to increase the breadth of cover and reduce the frequency of night work is not available.

Neonatal intensive care, in the experience of most paediatricians, is a specialty where a night bed on call is something to be savoured. Newborn babies in such units demand constant attention, from both medical and nursing staff. It is a credit to the hard work and commitment of the staff of these units that current neonatal survival rates in this country rival those achieved anywhere in the world. In addition to the heavy workload, the highly specialised nature of the work means that few doctors are prepared to do neonatal locum work, which increases the workload further.

I am sure that it was a simple oversight to exclude paediatric junior staff from the list of specialties with a particularly heavy burden of call out. Paediatrics is one of an all too long list of acute specialties that still have problems in achieving sensible staffing out of hours.

NeIl Marlow

Department of Child Health,

Liverpool Maternity Hospital,

Liverpool L7 7 BN

\section{Manpower}

SIR,-Now that discussions are taking place about the introduction of intermediate career posts in the hospital service, what is the future of many British citizens of Asian origin with "unlimited limited" registration? These are doctors who passed the old Temporary Registration Assessment Board examination, when temporary registration was unlimited in time, and whose rights were protected when limited registration was introduced. Are they eligible for these intermediate posts? If so will they be granted full registration or have they to suffer the ignominy of a second class registration for the rest of their working lives-without any hope of obtaining fult registration?

The Overseas Doctors' Association does not seem to be interested in the plight of these doctors. Perhaps the BMA, which has persistently adopted a stepmotherly attitude towards overseas doctors, might take this issue up on behalf of this silent minority, most, if not all, of whom are British citizens of Asian origin. If it does take this issue up the BMA will certainly prove to the outside world that it does care for all its members and the profession as a whole and will scotch the rumour that it ignores apartheid in our own backyand.

Leeds LS10 2LU

R MENON

\section{Drums begin to beat in the waiting list jungle}

SIR,-There is one aspect of the government's current drive to reduce waiting lists that causes some concern to junior doctors in our region, as I believe it does nationally.

As Dr Maureen Dalziel and Mr J Kerr state (21 March, $p$ 722), some health authorities have tried to shorten their waiting lists by encouraging doctors to carry out operating sessions and other routine work at weekends. We are concerned that junior doctors who are called on to assist at operations and with other routine work done at weekends should be rewarded satisfactorily. We believe that junior doctors should not be compelled to work outside their normal contracted hours to cover this routine work and that they should be paid for any work that they do outside their contracted hours at least at the standard rate for units of medical time. Furthermore, we believe that any doctors who find themselves doing routine work in time during which they are contracted to provide emergency cover (and are paid at the A UMT rate) should be reimbursed at at least the standard UMT rate.

Though we acknowledge the importance of reducing waiting lists and the sense in doing more routine work at weekends, we do not believe that these vote catching policies should be pursued at the expense of junior staff, who are already hard pressed. We would urge any junior doctor who finds himself working these extra hours to take it up with his local and national hospital junior staff committee.

BMA Trent Regional Office,

JEREMY WIGHT Chairman, Trent Hospital Junior Staff Committee

\section{The Savage inquiry}

SIR,-I wholeheartedly agree with Mrs Wendy Savage that it is a myth to consider that the events which led to her suspension were due to a clash of personalities ( $21 \mathrm{March}, \mathrm{p} 775$ ). If there has been any coolness in relationships it has been as a consequence rather than a cause of this affair, and we have both embarked on a course where cordial relations are being restored.

I would suggest, however, that it is a dramatisation of this affair to say that it was an expression of "fundamentally different approaches to the practice of obstetric medicine." I personally support the right of pregnant women to choose the most natural birth possible; my only and continuing concern is that these practices are conducted with due respect for the health and safety of the mother and unborn child. This is the issue that Mr Beaumont and his colleagues addressed, and their decision was happily favourable for Mrs Savage.

The London Hospital

J G GRUDZINSKAS London E1 1BB

\section{Scientifically Speaking}

SIR,- While not wishing to draw further attention to my work on campylobacters so generously spotlighted by Bernard Dixon (28 March, p 845), I must point out that the original thinking that lay behind the work was that of $\mathrm{Dr}$ (now Professor) Jean-Paul Butzler of Brussels.

The association between campylobacters and diarrhoea in man, first recognised by Elizabeth King in 1957 in the United States, ${ }^{1}$ was substantiated in Belgium in the early 1970s, when Butzler and Dekeyser successfully used a veterinary bacteriological method to isolate these organisms from the faeces of children suffering from acute diarrhoea. ${ }^{23}$ Theirs was the critical breakthrough, and it was their method that I used initially. It is odd that nobody took much notice of the Belgian papers, but I am very glad that I did. The one sad thing about the story is that Elizabeth King did not live to see her predictions about the role of these bacteria and their source in chickens come true in a way that even she probably did not imagine.

\section{B SKIRROW}

Department of Microbiology

Worcester Royal Infirmary,

Worcester WR1 3AS

King EO. Human infection's with Vibrio fetus and a closely related vibrio. $\mathcal{J}$ Infect $D$ is 1957;101:119-28.

Butzler JP, Dekeyser P, Detrain M, Dehaen F. Related vibrio in stools. F Pediatr 1973;82:493-5.

Dekeyser P, Gossuin-Detrain M, Butzler JP, Sternon J. Acute enteritis due to related vibrio: first positive stool cultures. f Infect Dis 1972;125:390-2. 